\title{
Assessment of Undiscovered Oil and Gas Resources of the Nile Delta Basin Province, Eastern Mediterranean
}

\author{
The U.S. Geological Survey estimated means of 1.8 billion barrels of recoverable oil, 223 trillion cubic \\ feet of recoverable gas, and 6 billion barrels of natural gas liquids in the Nile Delta Basin Province \\ using a geology-based assessment methodology.
}

\section{Introduction}

The U.S. Geological Survey (USGS) estimated the undiscovered oil and gas resources of the Nile Delta Basin Province as part of a program aimed at estimating the recoverable oil and gas resources of priority basins around the world. The province encompasses approximately 250,000 square kilometers of the eastern Mediterranean area (fig. 1). It is bounded to the west by the approximate edge of the Nile Cone, to the north by the Strabo, Pytheus, and Cyprus Trenches, to the east by the Levant Basin Province boundary, and to the south by the approximate edge of compressional structures in northern Egypt (Robertson, 1998; Roberts and Peace, 2007), which also corresponds to the general updip limit of Neogene deltaic strata in Egypt. This assessment was based on published geologic information and on commercial data from oil and gas wells, fields, and field production. The USGS approach is to define petroleum systems and geologic assessment units and assess the potential for undiscovered oil and gas resources.

\section{Composite Petroleum System and Assessment Units}

The Mesozoic-Cenozoic Composite Petroleum System was defined to include the possibility of viable source rocks of Jurassic, Cretaceous, Oligocene, Miocene, Pliocene, and Pleistocene ages (Abdel Aal and others, 2000, 2001; Dolson and others, 2001a, b; Vandre and others, 2007). Four assessment units (AU) were defined geologically within the composite petroleum system. Two of the assessment units-Eratosthenes Seamount AU and Mediterranean Ridge AU-were defined northward of the Nile Cone but were not quantitatively assessed. The two assessed areas are the Nile Cone AU and Nile Margin Reservoirs AU (figs. 1 and 2).

Oil and gas were generated from multiple Mesozoic and Cenozoic sources including: (1) hypothesized Jurassic marine and terrigenous shale; (2) Cretaceous argillaceous shales and limestones; (3) Oligocene and Miocene terrigenous source rocks; and (4) possibly biogenic sources (Vandre and others, 2007). Source rocks are thermally mature in deeper parts of the province (Abu El-Ella, 1990; Shaaban and others 2006). Petroleum charge is confirmed by more than 100 producing fields, numerous oil seeps, mud volcanoes, and gas chimneys imaged on seismic profiles (Loncke and others, 2004). Reservoirs are Mesozoic to Paleogene carbonate and clastic reservoirs and Neogene-Quaternary deltaic, nearshore marine, deep-water slope channel, and sheet and fan sandstones (Cross and others, 2009; Samuel and others, 2003) and Messinian-age (latest Miocene) incised-valley-fill deposits (Dolson and others, 2001a). Traps are structural and stratigraphic with numerous modifications because of inversion, salt removal, normal faults, growth faults, and mass transport (Loncke and others, 2006). Migration was enhanced by major intersecting fault systems. Lithologic and diagenetic seals were effective in creating pressure compartments (Nashaat, 1998).

The Nile Margin Reservoirs AU is assumed to be sourced from deeper thermally mature source rocks, but currently only one oil field of minimum size is present in the AU. The Nile Cone AU is thought to be sourced mainly from thermally mature Neogene deltaic source rocks, but also there might be a significant biogenic gas component (Vandre and others, 2007). The Nile Cone AU contains two oil fields and 126 gas fields.

The geologic model used in the assessment of the Nile Delta Basin was derived from comparison of geologic analogs, oil and gas production data, proved reserves, and potential oil and gas resources for the maturely explored Niger Delta Province (Brownfield and others, 2010). The 
USGS used a minimum undiscovered field size of 5 million barrels of oil equivalent (MMBOE).

\section{Assessment Results}

Estimates of volumes of undiscovered technically recoverable oil and gas resources are shown in table 1. The mean of the distribution for undiscovered oil is about 1,763 million barrels of oil (MMBO), with a range from $491 \mathrm{MMBO}$ to 4,266 MMBO. For undiscovered gas, the total mean volume is 223,242 billion cubic feet of gas (BCFG), with a range from 92,614 to 425,935 BCFG. For natural gas liquids, the total mean volume is 5,974 million barrels of natural gas liquids (MMBNGL), with a range of 2,451 to 11,464 MMBNGL. By far the largest resource is estimated to be in the Nile Cone $\mathrm{AU}$, with a mean volume of 217,313 BCFG and 5,789 MMBNGL. These estimates represent technically recoverable oil and gas resources; no attempt was made to estimate economically recoverable resources.

\section{References Cited}

Abu El-Ella, Ramadan, 1990, Maturation history of NeogeneQuaternary sediments, Nile Delta Basin, Egypt: American Association of Petroleum Geologists Bulletin, v. 74, no. 1, p. 77-84.

Abdel Aal, A., El Barkooy, A., Gerrits, M., Meyer, H., Schwander, M., and Zaki, H., 2000, Tectonic evolution of the eastern Mediterranean Basin and its significance for the hydrocarbon prospectively in the ultra-deepwater of the Nile Delta: The Leading Edge, October 2000, p. 1086-1102.

Abdel Aal, Ahmed, El Barkooky, Ahmed, Gerrits, Marc, Meyer, Hans-Jurg, Schwander, Marcus, and Zaki, Hala, 2001, Tectonic evolution of the eastern Mediterranean Basin and its significance for the hydrocarbon prospectively of the Nile Delta deepwater area: GeoArabia, v. 6, no. 3, p. 363-384.

Barber, P.M., 1981, Messinian subaerial erosion of the protoNile Delta: Marine Geology, v. 44, p. 253-272.

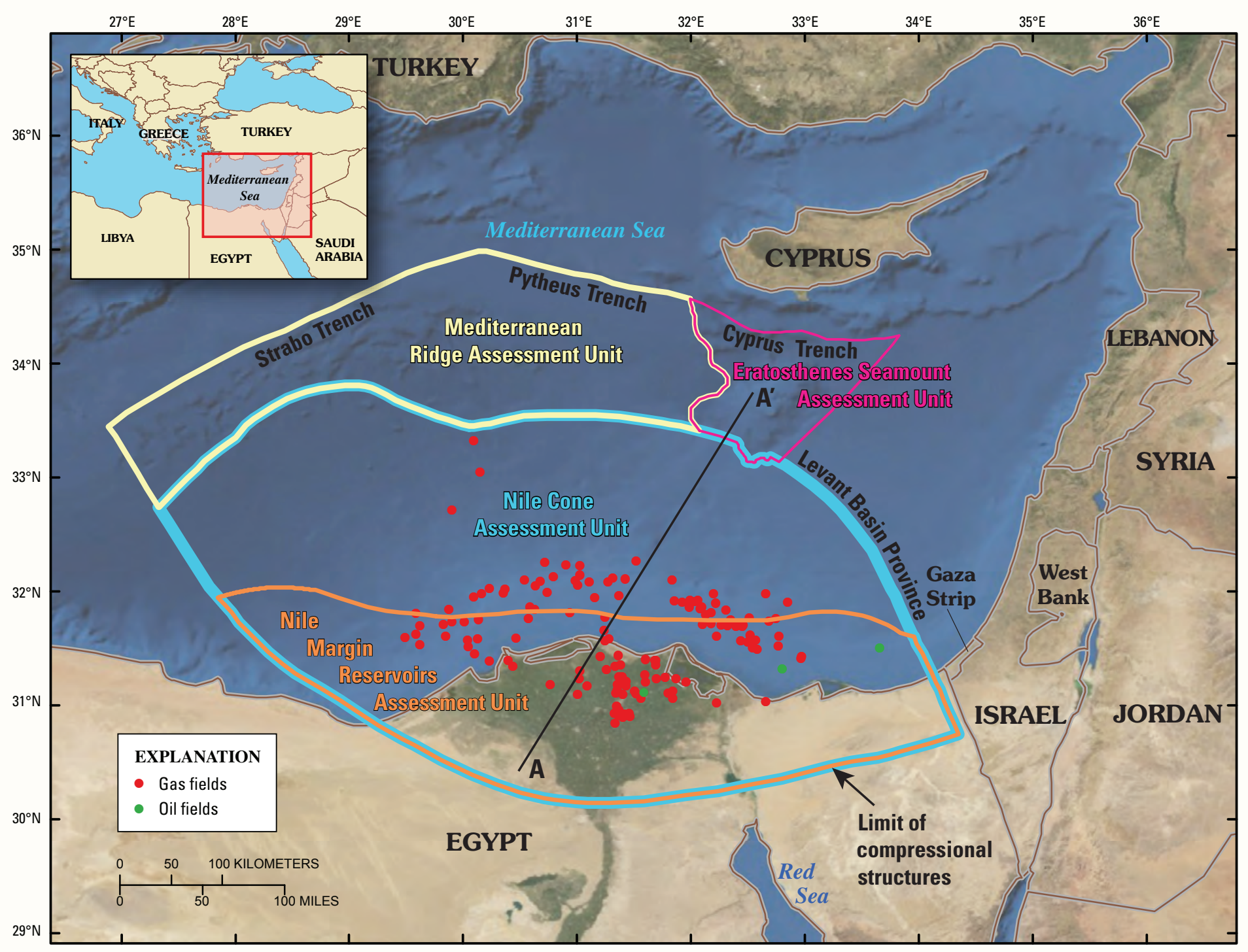

Figure 1. Location of four assessment units in the Nile Delta Basin Province in the eastern Mediterranean. (Map not definitive for political boundaries.) 
Brownfield, M.E, Charpentier, R.R., Cook, T.A., Klett, T.R., Pitman, J.K., Pollastro, R.M., Schenk, C.J., and Tennyson, M.E., 2010, Assessment of undiscovered oil and gas resources of four West Africa geologic provinces: U.S. Geological Survey Fact Sheet 2010-3006, 2 p.

Cross, N.E., Cummingham Alan, Cook, R.J., Taha, Amal, Esmaie, Eslam, and El Swidan, Nasar, 2009, Threedimensional seismic geomorphology of a deep-water slopechannel system: The Sequoia field, offshore west Nile Delta, Egypt: American Association of Petroleum Geologists, v. 93, no. 8, p. 1063-1086.
Dolson, J.C., Shann, M.V., Matbouly, Sayed, Harwood, Colin, Rashed, Rashed, and Hammouda, Hussein, 2001a, in Downey, M.W., Threet, J.C., and Morgan, W.A., eds., The petroleum potential of Egypt: Petroleum provinces of the twenty-first century: American Association of Petroleum Geologists Memoir No. 74, p. 453-482.

Dolson, J.C., Shann, M.V., Matbouly, S.I., Hammouda, Hussein, and Rashed, R.M., 2001b, Egypt in the twenty-first century: petroleum potential in offshore trends: GeoArabia, v. 6, no. 2, p. $211-230$.

Southwest

Northeast

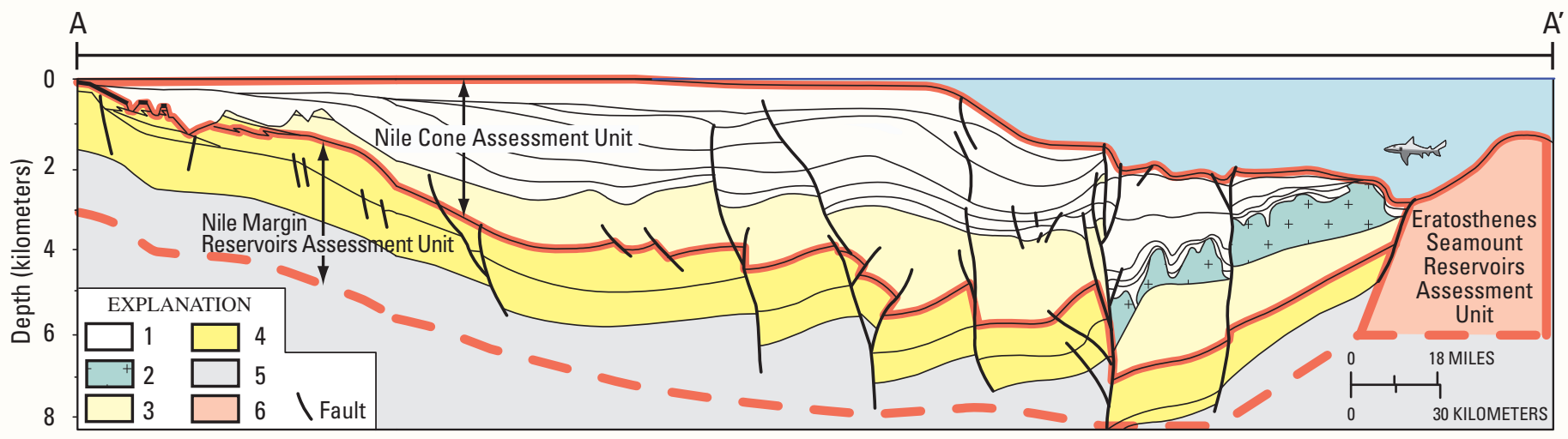

Figure 2. Schematic geologic cross section of the Nile Delta Basin Province illustrating the geologic definition of three of the four assessment units (AU) in this study (dotted red lines): Nile Margin Reservoir AU, Nile Cone AU, and Eratosthenes Seamount AU. The fourth AU, Mediterranean Ridge, is out of the plane of the cross section. Modified from Barber (1981) and Abdel Aal and others (2000). Location of projected section shown in figure 1. 1, Miocene (post-Messinian) and Pliocene-Quaternary; 2, Messinian Salt; 3, Miocene (pre-Messinian); 4, Paleogene-Cretaceous; 5, hypothesized pre-Cretaceous; 6, Eratosthenes Seamount.

Table 1. Nile Delta Basin Province assessment results.

[MMBO, million barrels of oil. BCFG, billion cubic feet of gas. MMBNGL, million barrels of natural gas liquids. Results shown are fully risked estimates. For gas accumulations, all liquids are included as NGL (natural gas liquids). Undiscovered gas resources are the sum of nonassociated and associated gas. F95 represents a 95 percent chance of at least the amount tabulated; other fractiles are defined similarly. Largest expected oil field in MMBO; largest expected gas field in BCFG. TPS, total petroleum system; $\mathrm{AU}$, assessment unit. Gray shading indicates not applicable]

\begin{tabular}{|c|c|c|c|c|c|c|c|c|c|c|c|c|c|c|}
\hline \multirow{3}{*}{$\begin{array}{l}\text { Total Petroleum Systems } \\
\text { (TPS) } \\
\text { and Assessment Units (AU) }\end{array}$} & \multirow{3}{*}{$\begin{array}{l}\text { Field } \\
\text { type }\end{array}$} & \multirow{3}{*}{$\begin{array}{c}\text { Expected } \\
\text { largest } \\
\text { mean } \\
\text { field size } \\
\end{array}$} & \multicolumn{12}{|c|}{ Total undiscovered resources } \\
\hline & & & \multicolumn{4}{|c|}{ Oil (MMBO) } & \multicolumn{4}{|c|}{ Gas (BCFG) } & \multicolumn{4}{|c|}{ NGL (MMBNGL) } \\
\hline & & & F95 & F50 & F5 & Mean & F95 & F50 & F5 & Mean & F95 & F50 & F5 & Mean \\
\hline \multicolumn{15}{|c|}{ Nile Delta Basin Province, Mesozoic-Cenozoic Composite TPS } \\
\hline \multirow{2}{*}{ Nile Margin Reservoirs AU } & Oil & \begin{tabular}{|r|}
214 \\
\end{tabular} & 449 & 1,150 & 2,600 & 1,288 & 551 & 1,425 & 3,237 & 1,597 & 11 & 29 & 66 & 32 \\
\hline & Gas & 766 & & & & & 698 & 2,193 & 5,750 & 2,574 & 21 & 68 & 181 & 80 \\
\hline \multirow{2}{*}{ Nile Cone AU } & Oil & 311 & 42 & 256 & 1,666 & 475 & 152 & 930 & 6,123 & 1,758 & 6 & 38 & 255 & 73 \\
\hline & Gas & 17,194 & & & & & 91,213 & 197,850 & 410,825 & 217,313 & 2,413 & 5,269 & 10,962 & 5,789 \\
\hline Eratosthenes Seamount AU & \multicolumn{14}{|c|}{ Not quantitively assessed } \\
\hline Mediterranean Ridge AU & \multicolumn{14}{|c|}{ Not quantitively assessed } \\
\hline $\begin{array}{l}\text { Total Conventional } \\
\text { Resources }\end{array}$ & & & 491 & 1,406 & 4,266 & 1,763 & 92,614 & 202,398 & 425,935 & 223,242 & 2,451 & 5,404 & 11,464 & 5,974 \\
\hline
\end{tabular}


Loncke, Lies, Mascle, Jean, and the Fanil Scientific Parties, 2004, Mud volcanoes, gas chimneys, pockmarks and mounds in the Nile deep-sea fan (Eastern Mediterranean): Geophysical evidences: Marine and Petroleum Geology, v. 21, p. 669-689.

Loncke, Lies, Gaullier, Virginie, Mascle, Jean, Vendeville, Bruno, and Camera, Laurent, 2006, The Nile deep-sea fan: An example of interacting sedimentation, salt tectonics, and inherited subsalt paleotopographic features: Marine and Petroleum Geology, v. 23, p. 297-315.

Nashaat, M., 1998, Abnormally high formation pressure and seal impacts on hydrocarbon accumulations in the Nile Delta and North Sinai Basins, Egypt, in Law, B.E., Ulmishek, G.F., and Slavin, V.I., eds., Abnormal pressures in hydrocarbon environments: American Association of Petroleum Geologists Memoir no. 70, p. 161-180.

Roberts, Glyn, and Peace, David, 2007, Hydrocarbon plays and prospectively of the Levantine Basin, offshore Lebanon and Syria from modern seismic data: GeoArabia, v. 12, no. 3, p. 99-124.
Robertson, A.H.F., 1998, Mesozoic-Tertiary tectonic evolution of the easternmost Mediterranean area: Integration of marine and land evidence, in Robertson, A.H.F., Emeis, K.C., Richter, C., and Camerlenghi, A., eds., Proceedings of the Ocean Drilling Program, Scientific Results, v. 160, p. 723-782.

Samuel, Andy, Kneller, Ben, Raslan, Samir, Sharp, Andy, and Parsons, Cormac, 2003, Prolific deep-marine slope channels of the Nile Delta, Egypt: American Association of Petroleum Geologists, v. 87, no. 4, p. 541-560.

Shaaban, F., Lutz, R., Littke, R., Bueker, C., and Odisho, K., 2006, Source-rock evaluation and basin modeling in NE Egypt (NE Nile Delta and northern Sinai): Journal of Petroleum Geology, v. 29, no. 2, p. 103-124.

Vandre, Claudius, Cramer, Berhard, Gerling, Peter, and Winsemann, Jutta, 2007, Natural gas formation in the western Nile delta (Eastern Mediterranean): Thermogenic versus microbial: Organic Geochemistry, v. 38, p. 523-539.

\section{For Further Information}

A publication detailing the geology and the methodology for the Nile Basin Province assessment is in progress. Assessment results are available at the USGS Energy Program website, http://energy.cr.usgs.gov/oilgas/.

\section{Nile Delta Basin Province Assessment Team}

Mark A. Kirschbaum (mkirsch@usgs.gov), Christopher J. Schenk, Ronald R. Charpentier, Timothy R. Klett, Michael E. Brownfield, Janet K. Pitman, Troy A. Cook, and Marilyn E. Tennyson. 